\title{
Helminth fauna of chiropterans in Amazonia: biological interactions between parasite and host
}

\author{
Ana Cláudia Alexandre de Albuquerque ${ }^{1}$. Marcela Figueiredo Duarte Moraes ${ }^{1}$. \\ Ana Carolina Silva ${ }^{1}$ Ivan Moura Lapera ${ }^{1}$ - José Hairton Tebaldi ${ }^{1}$. \\ Estevam G. Lux Hoppe ${ }^{1}$
}

Received: 15 April 2016 / Accepted: 20 April 2016/Published online: 28 April 2016

(C) Springer-Verlag Berlin Heidelberg 2016

\begin{abstract}
Amazonia, the largest Brazilian biome, is one of the most diverse biomes around the world. Considering the Brazilian chiropteran species, 120 out of known 167 species are registered in Pará state, with 10 endemic species. Despite the high diversity of bats in Amazonia, studies on their parasites, especially on helminths, are scarce. Therefore, the present study aims to study the helminth fauna of different bats from the Pará state, Amazon biome, determine the descriptors of infection, and evaluate the host-parasite interactions, as well as evaluate differences in ecological indexes in accordance with the feeding guilds. The study was developed on 67 bats of 21 species captured in several areas of the Pará state. The animals were identified, divided into feeding guilds, and necropsied. The parasites obtained were identified and quantified. A total of 182 parasites were found in $20.89 \%$ of the studied bats, representing nine species, as follows: Anenterotrema eduardocaballeroi, Anenterotrema liliputianum, Ochoterenatrema caballeroi, Tricholeiperia sp., Parahistiostrongylus octacanthus, Litomosoides guiterasi, Litomosoides brasiliensis, Capillariinae gen. sp., and Hymenolepididae gen. sp. Also, the results indicated that there was no impact of parasitism on host body condition and no relationship between sex and parasite intensity. In relation to the feeding guilds, the omnivores showed higher prevalence and mean intensity. Animals from regions closer to the equator tend to have greater richness in parasite species, but the present study revealed low diversity and richness in
\end{abstract}

Estevam G. Lux Hoppe

e.hoppe@gmail.com; hoppe@fcav.unesp.br

1 Faculdade de Ciências Agrárias e Veterinárias, Departamento de Medicina Veterinária Preventiva e Reprodução Animal, Universidade Estadual Paulista - Unesp, Via Prof. Paulo Donato Castellane km 05, 14884-900 Jaboticabal, SP, Brazil species. In conclusion, the ecological pattern observed for other animal groups, in which higher parasitic diversity are registered in lower latitudes, is not applicable to chiropterans from the study area.

Keywords Helminth $\cdot$ Bats $\cdot$ Biodiversity $\cdot$ Feeding guild . Brazil

\section{Introduction}

Brazil has the largest proportion of the Amazon biome, an area of $4,196,943 \mathrm{~km}^{2}$ that corresponds to about $50 \%$ of the national territory. The Amazon biome spans nine states: Amazonas, Pará, Mato Grosso, Acre, Rondônia, Roraima, Amapá, a portion of Tocantins, and Maranhão (MMA 2014). Amazon forest is known to hold the largest variety of plants and animal species in the world, also harboring a large genetic diversity (Marcon et al. 2012).

Bats are wild animals belonging to the order Chiroptera, which includes about $25 \%$ of mammals in all existing fauna (Pinheiro et al. 2013). These animals have huge importance to the ecosystem they belong because they play different roles in tropical communities (Reis et al. 2000; Miretzki 2003).

In Brazil, 167 species of chiropterans are described, belonging to nine families and 64 genera, representing $15 \%$ of bat richness around the planet. A large portion of these species is located in the Amazon biome, a total of 146 species are registered, and 46 of restricted occurrence in this area (Reis et al. 2007; Peracchi et al. 2010; Bernard et al. 2011). The Pará state has the largest variety of chiropterans among the states inside the Amazon forest, accounting 120 registered species (Bernard et al. 2011).

The endoparasite diversity of bats includes nematodes, cestodes, trematodes, and acanthocephalan (Santos and Gibson 
2015). However, despite the huge amount of bat species registered in Brazil, there are only a few studies about their occurrence, identification, and morphological description, especially in the Amazon (Santos and Gibson 1998; Nogueira et al. 2004; Pinheiro et al. 2013).

Bats are interesting species to be investigated, as they have characteristics that facilitate transmission and spread of parasites, such as their flight ability, being able to transport parasites over long distances, the social behavior living in single or mixed colonies, facilitating the occurrence of interspecific associations, and the ability to use various types of harborage, including near human habitations (Wimsatt 1970; Saoud and Ramadan 1976).

Endoparasitism in bats may be associated with various intrinsic and extrinsic factors of host and its habitat (Bordes and Morand 2008; Pinheiro et al. 2013). The host factors may depend on ecologic aspects, immune response, food habits, and foraging strategy (Poulin and Morand 2000; Bordes and Morand 2008), also be related to environment and weather influences (Von Zuben 1997; Bordes and Morand 2008). The authors Poulin and Morand (2000) support the hypothesis that parasite diversity determinant is the type of host, due host is their main habitat.

Thus, it is important to elucidate the role parasites play in ecosystems as well as areas of high and low of parasite diversity, for the complete knowledge of their influence on the biosphere (Silva 2012). Considering these factors, the aim of this study was to verify the occurrence of helminths in different species of chiropters in the Amazon biome, relate the infection index with phenotypical aspects of the hosts, and assess ecological indexes of populations of each feeding guild.

\section{Material and methods}

\section{Animals and study area}

The animals used in this study were from Pará state, north of Brazil, captured in the cities: Portel, Dom Eliseu, Augusto Correa, Tracuateua, Bragança, São João de Pirabas, Viseu, Capanema, São Domingos do Capim, Cachoeira do Piriá, Marabá, Altamira, Belém, Ananindeua, Castanhal, Mosqueiro, Outeiro, and Inhangapi (Fig. 1).

Among animals used in this study, 59 were obtained from captures made in 2013 by Secretarias de Saúde dos Municípios and Centro de Controle de Zoonoses do Estado do Pará (CCZ) to perform rabies diagnostic examination in Laboratório de diagnóstico de Raiva and Seção de Arbovirologia e Febres Hemorrágicas at Instituto Evandro Chagas in Belém, Pará state.

Other animals were captured by "Projeto de Monitoramento de Quirópteros" developed by the company Biota Ltd. in Belo Monte Hydroelectric Dam, at Altamira city, Pará state. Only animals that died during manipulation were used. Taxonomic identification of the hosts was based on Vizotto \& Taddei (1973) and Reis et al. (2013), and the development stage was performed according to Anthony (1988).

\section{Necropsy and harvested material}

The animals were stored in a freezer at $-20^{\circ} \mathrm{C}$ until the time of necropsy. Then, the specimens were thawed at room temperature, and the biometry of the animals was performed, measuring the length of the right carpus with the aid of a caliper and digital balance.

After biometrics, the thoracic and abdominal cavities were opened to remove the organs in block and careful inspection of these cavities searching for possible parasites. The intestine was individualized and fixed in ethanol $70 \%$ then sent to Laboratório de Enfermidades Parasitárias dos Animais in FCAV, at Unesp, in Jaboticabal city, São Paulo state. At this location, a longitudinal opening of the intestines in Petri dishes with the aid of a stereomicroscope was performed with profuse washing of the mucosa with ethanol $70^{\circ}$. Endoparasites obtained were stored and preserved in labeled bottles containing ethanol $70^{\circ}$ for further identification and counting.

\section{Helminth identification and description}

In order to study the morphology of parasite helminths, the obtained specimens were cleared in acetic acid $80 \%$ and beechwood creosote. Images of parasites were obtained by means of an Olympus BX-51 microscope (Olympus, Melville, NY) equipped with a digital camera QColor 3. The helminths were identified according to Travassos et al. (1969), Vicente et al. (1997), and Khalil et al. (1994) surveys. They were deposited in a helminth collection in Laboratório de Enfermidades Parasitárias dos Animais in FCAV at Unesp, located in Jaboticabal city, São Paulo state.

\section{Scanning electron microscopy}

The best helminth specimens were selected for scanning electron microscopy (SEM). Initially, the helminths were cleaned by agitation in glutaraldehyde $2.5 \%$, postfixed in osmium tetroxide $2 \%$ at $23{ }^{\circ} \mathrm{C}$ during $12 \mathrm{~h}$, dehydrated in graded ethanol series, and dried in a critical point with liquid $\mathrm{CO}_{2}$. After drying, the best specimens were cut if necessary and mounted on appropriate bases for SEM with stereoscopic microscope. After metallization, they were examined under a JEOL JSM-5410 scanning electron microscope operating at $15 \mathrm{kV}$ that belongs to Laboratório de Nematologia of Departamento de Fitossanidade, in FCAV at Unesp, located in Jaboticabal city, São Paulo state. Images were obtained that allowed to understand or elucidate the morphology structures of parasite taxonomic relevance. 


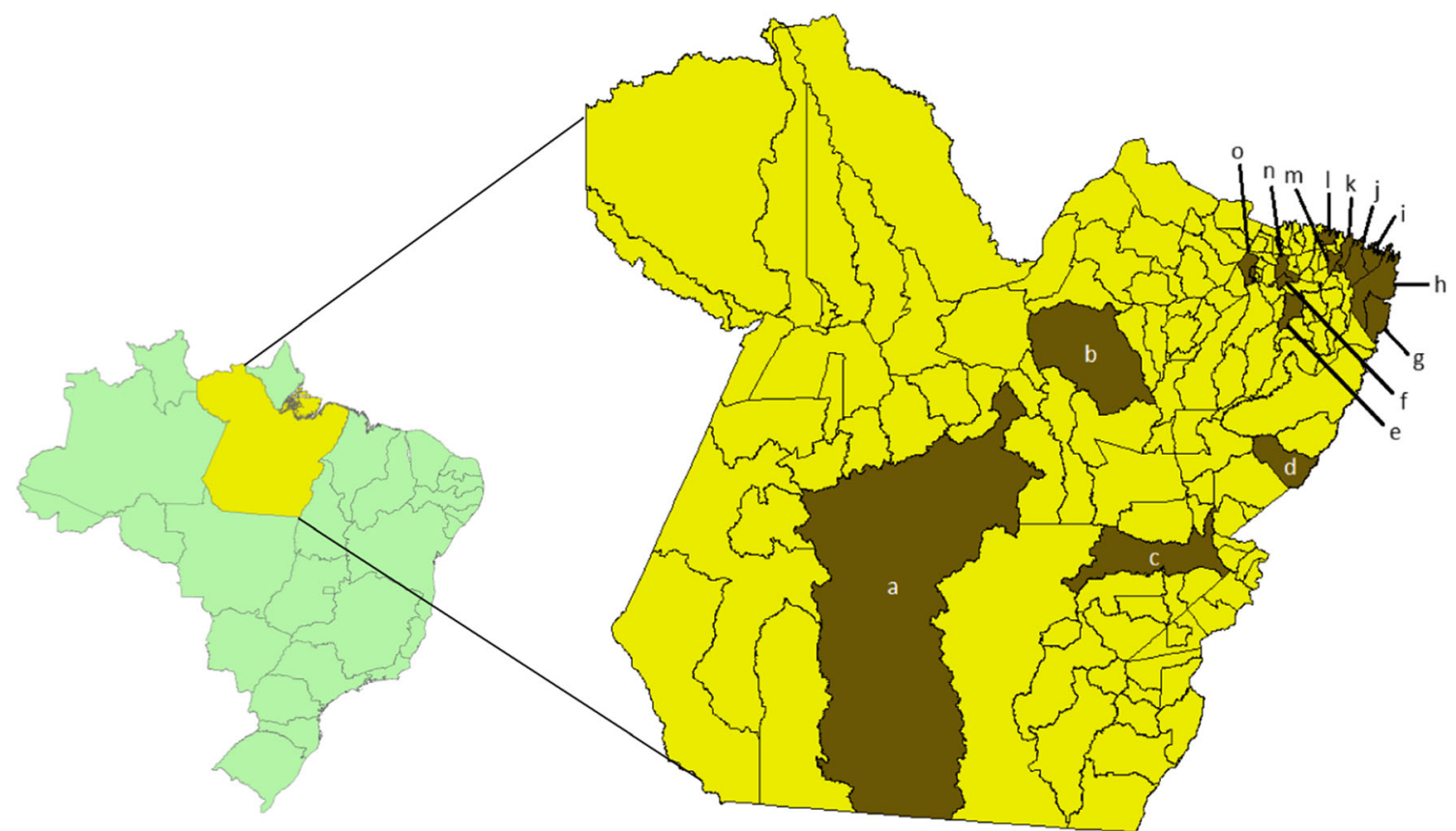

Fig. 1 Map of Brazil, highlighting Pará state. Cities where bat collections were performed are brown. (a) Altamira; (b) Portel; (c) Marabá; (d) Dom Eliseu; (e) São Domingos do Capim; $(f)$ Inhangapi; $(g)$ Cachoeira do

\section{Statistical analyses}

Indicators of helminth infection, average intensity, and average abundance were calculated after identification and count of the parasites, according to Bush et al. (1997). Hosts were separated and classified in feeding guilds. They were classified into four groups: frugivorous, omnivores, insectivores, and nectarivores, for direct comparison of Shannon diversity index and Simpson dominance. The same indexes were calculated for total bat population.

The ratio between parasite intensity and the host sex was assessed by Mann-Whitney test, according to value distribution. The ratio between infection prevalence and the sex was assessed by the Fisher exact test.

For the establishment of body conditions in this study, we used the length and weight of the forearm of each individual (Lewis 1996). To avoid interferences of body condition results, young and pregnant animals were not considered. The evaluation of endoparasite impact on body conditions was performed by Spearman's rank correlation method. Ecological analyses were made using Biodiversity software Pro 2.0. Statistical analysis was made using GraphPad Prism software 5.0, with the adjusted significance level at 0.05 .

\section{Ethical aspects}

All the procedures involving animals adopted in this study are according to international ethical standards and were approved by the Animal Use Ethics Committee of the FCAV/
Piriá; (h) Viseu; ( $i$ ) Augusto Corrêa; $(j)$ Bragança; $(k)$ Tracuateua; $(l)$ São João de Pirabas; $(m)$ Capanema; $(n)$ Castanhal; and $(o)$ metropolitan area of Belém: Belém, Ananindeua, Outeiro, Mosqueiro

Unesp (07554/14) and by Brazilian environmental agency (SISBIO license n. 43913-1).

\section{Results}

We sampled 67 chiropterans at different development stages, males and females, belonging to six families and separated in four feeding guilds (Table 1). Among the 67 chiropterans examined, $20.89 \%$ (14/67) had at least one helminth species. The infected animals comprised ten males and four females. Among the infected males, nine were adults and one was young and, regarding the females, three were adults and one was a youngling. A total of 182 specimens of helminths were identified, representing the classes Digenea, Cestoidea, and Nematoda. The diagnosed species and the descriptors of infection are listed in Table 2. The trematodes Anenterotrema liliputianum Travassos, 1928; Anenterotrema eduardocaballeroi Freitas, 1960; and Ochoterenatrema caballeroi Freitas, 1957 were the most abundant, showing the highest prevalence rates, mean intensities, and abundances (Table 2). Each of these species of helminths Litomosoides brasiliensis Almeida, 1936; Litomosoides guiterasi Vigueras, 1934; Parahistiostrongylus octacanthus Lent \& Freitas (Fig. 2), 1940; Tricholeiperia sp. Travassos, 1935 (Fig. 2); Hymenolepididae gen. sp., Ariola 1899; and Capillariinae gen. sp. Railliet, 1915 were found in different species of bats (Table 2).

Among the infected animals, $78 \%$ (11/14) were parasitized by trematodes. Compared to the other helminth groups, the 
Table 1 Relation of species of necropsied bats, containing number of specimens, family, developmental stage, sex, and eating habits

\begin{tabular}{|c|c|c|c|c|c|c|}
\hline \multirow[t]{2}{*}{ Species } & \multicolumn{2}{|c|}{ Young bats $(n)$} & \multicolumn{2}{|c|}{ Adult bats $(n)$} & \multirow[t]{2}{*}{$\mathrm{N}^{\circ}$ specimens } & \multirow[t]{2}{*}{ Eating habit } \\
\hline & Males & Females & Males & Females & & \\
\hline \multicolumn{7}{|l|}{ Phyllostomidae } \\
\hline Artibeus cinereus & 0 & 1 & 0 & 0 & 1 & Frugivorous \\
\hline Artibeus planirostris & 0 & 1 & 3 & 2 & 6 & Frugivorous \\
\hline Artibeus lituratus & 0 & 0 & 1 & 1 & 2 & Frugivorous \\
\hline Carollia perspicillata & 2 & 3 & 12 & 9 & 26 & Frugivorous \\
\hline Uroderma bilobatum & 0 & 0 & 1 & 0 & 1 & Frugivorous \\
\hline Sturnira lilium & 0 & 0 & 0 & 2 & 2 & Frugivorous \\
\hline Glossophaga soricina & 0 & 1 & 4 & 1 & 6 & Nectarivore \\
\hline Lionycteris spurrelli & 0 & 0 & 1 & 0 & 1 & Nectarivore \\
\hline Phyllostomus hastatus & 0 & 0 & 1 & 0 & 1 & Omnivore \\
\hline Phyllostomus discolor & 0 & 0 & 1 & 0 & 1 & Omnivore \\
\hline Mimon crenulatum & 0 & 0 & 0 & 1 & 1 & Insectivore \\
\hline \multicolumn{7}{|l|}{ Molossidae } \\
\hline Eumops auripendulus & 1 & 0 & 0 & 0 & 1 & Insectivore \\
\hline Eumops glaucinus & 0 & 1 & 0 & 0 & 1 & Insectivore \\
\hline Molossus molossus & 1 & 0 & 4 & 2 & 7 & Insectivore \\
\hline Molossus rufus & 0 & 1 & 2 & 0 & 3 & Insectivore \\
\hline Nyctinomps sp. & 0 & 0 & 0 & 1 & 1 & Insectivore \\
\hline \multicolumn{7}{|l|}{ Vespertilionidae } \\
\hline Myotis riparius & 0 & 0 & 0 & 1 & 1 & Insectivore \\
\hline Myotis nigricans & 1 & 0 & 0 & 1 & 2 & Insectivore \\
\hline \multicolumn{7}{|l|}{ Natalidae } \\
\hline Natalus espiritosantense & 0 & 0 & 1 & 0 & 1 & Insectivore \\
\hline \multicolumn{7}{|l|}{ Emballonuridae } \\
\hline Peropteryx kappleri & 0 & 0 & 0 & 1 & 1 & Insectivore \\
\hline \multicolumn{7}{|l|}{ Mormoopidae } \\
\hline Pteronotus gymnonotus & 0 & 0 & 0 & 1 & 1 & Insectivore \\
\hline Total & 5 & 8 & 31 & 23 & 67 & \\
\hline
\end{tabular}

trematodes showed the largest prevalence, $95.6 \%(174 / 182)$. The bat Carollia perspicillata Linnaeus, 1758 displayed the highest parasite richness, with five species of helminths.

Considering the studied bat population, the observed Shannon and Simpson indexes were 1.235 and 0.03324, respectively. These indexes indicate low diversity and low dominance of the parasite species, respectively. Regarding the feeding guilds, the insectivorous bats showed the highest diversity and the omnivorous bats, in turn, presented the highest value of Simpson dominance index, indicating dominance of one species (Table 3). Also, the omnivorous guild obtained the highest rate of prevalence and average intensity of parasites (Figs. 3 and 4).

There was no significant difference between parasite intensity of males and females ( $P=0.1083, U=464.0)$, and statistically, there was no ratio between infection prevalence and sex $(P=0.2314)$, also there was no impact on endoparasites regarding body conditions of their hosts $(r=-0.06653$, $P=0.6360)$.
All identified helminths in the present study represent new locality records. The bat species Phyllostomus hastatus, Glossophaga soricina, and $C$. perspicillata represent new host records for the A. liliputianum. C. perspicillata is a new host record for $A$. eduardocaballeroi. Also, $C$. perspicillata and Peropteryx kappleri are new host records for the trematode $O$. caballeroi. The filarial nematode $L$. brasiliensis was first registered in Artibeus planirostris (Table 4).

\section{Discussion}

Feeding habits are one of the factors related to endoparasitism in bats (Bordes and Morand 2008). The higher prevalences and intensity of infection found in omnivorous bats prove this affirmation, as these bats have more diverse feeding habits when compared to the other feeding guilds, increasing the chances of infection. Other 
Table 2 Helminth infection indicators observed in bats belonging to the Amazon biome

\begin{tabular}{|c|c|c|c|c|c|}
\hline Helminths & $\begin{array}{l}\text { Specimen } \\
\text { quantity }\end{array}$ & Infected hosts & Prevalence $(\%)$ & $\begin{array}{l}\text { Average } \\
\text { intensity }\end{array}$ & $\begin{array}{l}\text { Average } \\
\text { abundance }\end{array}$ \\
\hline \multicolumn{6}{|l|}{ Digenea } \\
\hline \multicolumn{6}{|l|}{ Anenterotrematidae } \\
\hline Anenterotrema liliputianum & 79 & $\begin{array}{l}\text { Carollia perspicillata, Molossus rufus, } \\
\text { Glossophaga soricina, Phyllostomus hastatus }\end{array}$ & 5.97 & $19.75(1-48)$ & 1.18 \\
\hline $\begin{array}{l}\text { Anenterotrema } \\
\text { eduardocaballeroi }\end{array}$ & 61 & $\begin{array}{l}\text { Carollia perspicillata, Molossus molossus, } \\
\text { Phyllostomus hastatus }\end{array}$ & 5.97 & $15.25(5-36)$ & 0.91 \\
\hline \multicolumn{6}{|l|}{ Lecithodendriidae } \\
\hline Ochoterenatrema caballeroi & 34 & $\begin{array}{l}\text { Carollia perspicillata, Molossus molossus, } \\
\quad \text { Peropteryx kappleri }\end{array}$ & 4.48 & $11.33(2-20)$ & 0.51 \\
\hline \multicolumn{6}{|l|}{ Cestoidea } \\
\hline Hymenolepididae gen. sp. & 1 & Artibeus planirostris & 1.49 & 1.00 & 0.01 \\
\hline \multicolumn{6}{|l|}{ Nematoda } \\
\hline \multicolumn{6}{|l|}{ Filariidae } \\
\hline Litomosoides brasiliensis & 1 & Artibeus planirostris & 1.49 & 1.00 & 0.01 \\
\hline Litomosoides guiterasi & 1 & Carollia perspicillata & 1.49 & 1.00 & 0.01 \\
\hline \multicolumn{6}{|l|}{ Molineidae } \\
\hline Tricholeiperia sp. & 3 & Carollia perspicillata & 2.99 & 1.50 & 0.04 \\
\hline Parahistiostrongylus octacanthus & 1 & Phyllostomus hastatus & 1.49 & 1.00 & 0.01 \\
\hline \multicolumn{6}{|l|}{ Trichuridae } \\
\hline Capillariinae gen. sp. & 1 & Phyllostomus hastatus & 1.49 & 1.00 & 0.01 \\
\hline
\end{tabular}

studies show insectivores with higher prevalences in comparison to other feeding guilds (Lima et al. 2001; Cardia 2012).
In a survey performed in Amazon with fruit bats sampled in forest areas, there was a richness of four helminth species (Nogueira et al. 2004), which is lower than that
Fig. 2 Photomicrophagy light microscopy: a the anterior portion of adult female $P$. octacanthus, clarified in $80 \%$ acetic acid and beech creosote, found in $P$. hastatus, bar $100 \mu \mathrm{m}$; b anterior portion of adult female Tricholeiperia sp., clarified in acetic acid $80 \%$ and beech creosote, found in $C$. perspicillata, bar $100 \mu \mathrm{m}$. Photomicrography in scanning electron microscope $15 \mathrm{kV}$ : c anterior portion of adult female $P$. octacanthus, showing cephalic end with eight large thorns, bar $50 \mu \mathrm{m} ; \mathbf{d} 10 \mu \mathrm{m}$ a
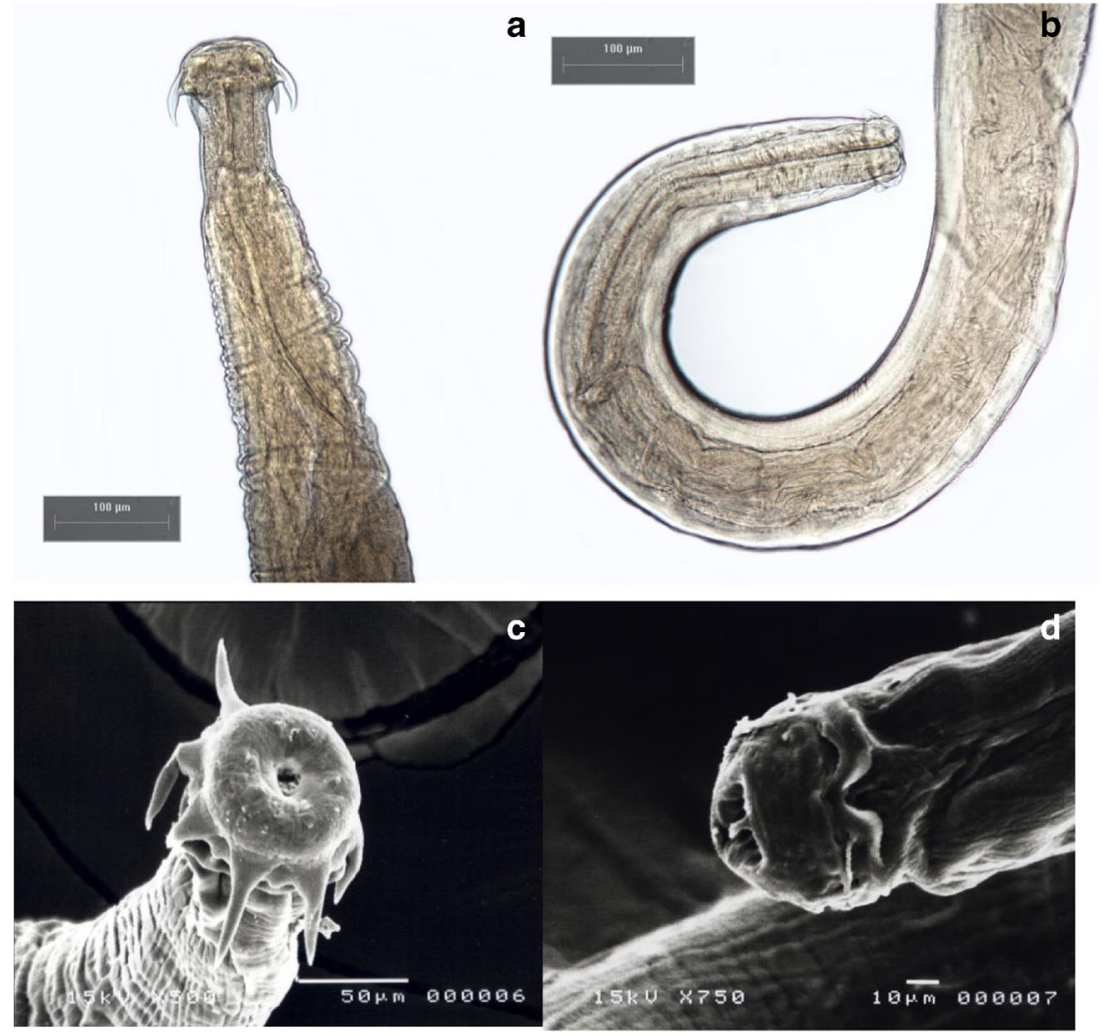
Table 3 Ecological indicators for feeding guilds of chiropters captured in Amazon biome, in Pará state, Brazil

\begin{tabular}{lll}
\hline Guild & Shannon index $\left(\mathrm{H}^{\prime}\right)$ & Simpson index (D) \\
\hline Frugivorous & 0.9703 & 0.5311 \\
Insectivore & 0.9831 & 0.3886 \\
Omnivore & 0.4825 & 0.7663 \\
Nectarivore & - & - \\
\hline
\end{tabular}

observed in the present study, accounting nine species. A difference in richness may be related to feeding habits analyzed in the present study, as four feeding guilds were analyzed. However, even if only compared to the fruit bats, richness would still be greater in the present study. The prevalence found by Nogueira et al. (2004) was greater $(26 \%)$ than the current research $(20.89 \%)$. It is suggested that this difference in prevalence is due to the animals collected in localities since bats used in this study were collected in urban or peri-urban areas, favoring a smaller population density of these species. It is known that hosts that have social behavior live at high-population density or in constant contact between species have a greater number of parasites (Lindenfors et al. 2007).

Latitude is an important geographical factor that may influence parasite richness and species diversity in wild animals (Poulin; Morand, 200). There is the assertation that both parasite diversity and species richness of parasites may increase according to proximity with the Equator (Poulin and Morand 2000; Lindenfors et al. 2007). While studied animals were captured in low-latitude region, close to the Equator, lower parasitic richness and parasitic diversity compared to bats in other regions of higher latitude in Brazil was observed (Melo 2010; Cardia 2012), indicating that the influence of latitude in parasite richness and parasitic diversity does not apply to helminth investigations of bats.

Parasite species found in chiropterans in the present study were different than those described by Nogueira et al. (2004), who obtained the following species Hasstilesia tricolor, Vampirolepis elongatus, Capillaria sp., and Cheiropteronema globocepha in Amazon. However, in both studies, trematodes have the highest intensity of parasites found. The same was observed in other studies of bat endoparasites in other countries (Saoud and Ramadan 1976; Esteban et al., 2001; Lord et al. 2012). This fact may be related to two factors: ingestion of an intermediate host, in the case of insects and mollusks, or by other means of infection such as water ingestion containing cercariae (Nogueira et al. 2004; Lord et al. 2012).

Parasites can affect the fitness of their hosts by influencing traits like their behavior, immune responses, and body condition (Lourenço and Palmeirin 2007). However, the present results did not reveal any impact of parasitism on the body condition of the studied hosts, as was observed in another study in Amazonian bats (Nogueira et al. 2004). Other studies performed with ectoparasites of bats also established body condition considering weight and length of forearm (Lewis 1996; Zahn and Rupp 2004; Lourenço and Palmeirin 2007).Lewis (1996)found a negative correlation between body condition and number of ectoparasites in lactating females, but this result was potentially confounded by changes in the mass of lactating females over time, Lourenço and Palmeirin (2007) found a negative correlation too, but they analyzed males and females at several development stages, and they suggest that the parasitism can influence the host social structure.

In mammals, differences between parasitism in males and females are expected, as the sexual hormones have different effects on the host immune response (Esteban et al. 2001;
Fig. 3 Prevalence of endoparasites, according to feeding guilds of bats captured in Amazon biome, Pará state, Brazil

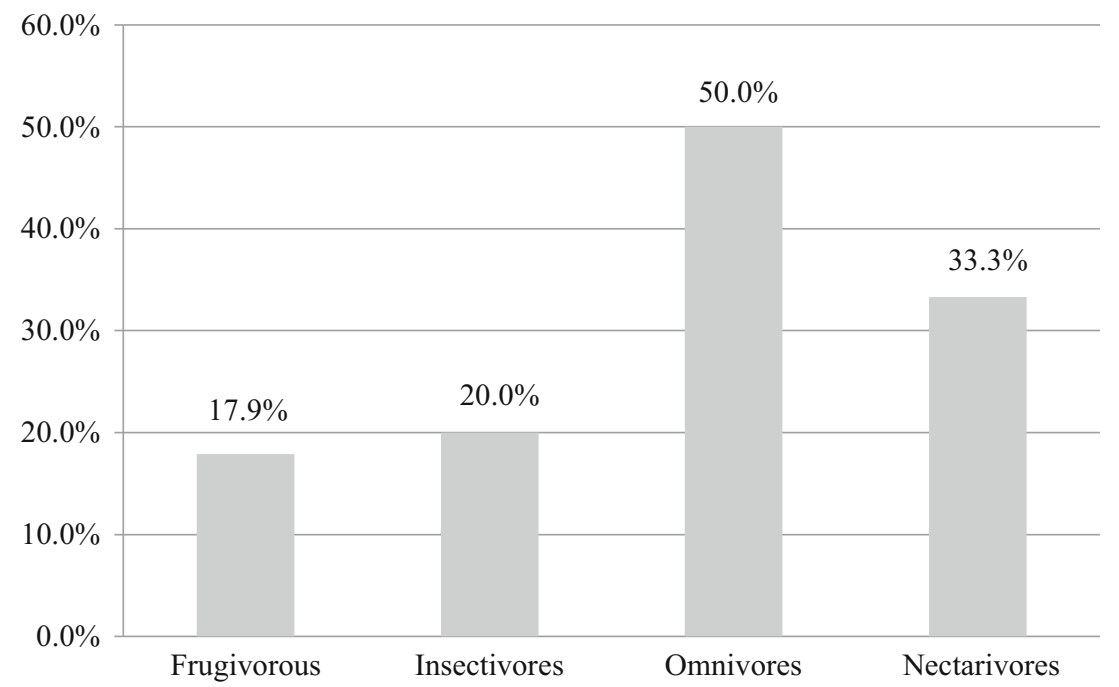


Fig. 4 Parasitic average intensity, according to feeding guilds of chiropters captured in Amazon biome, Pará state, Brazil

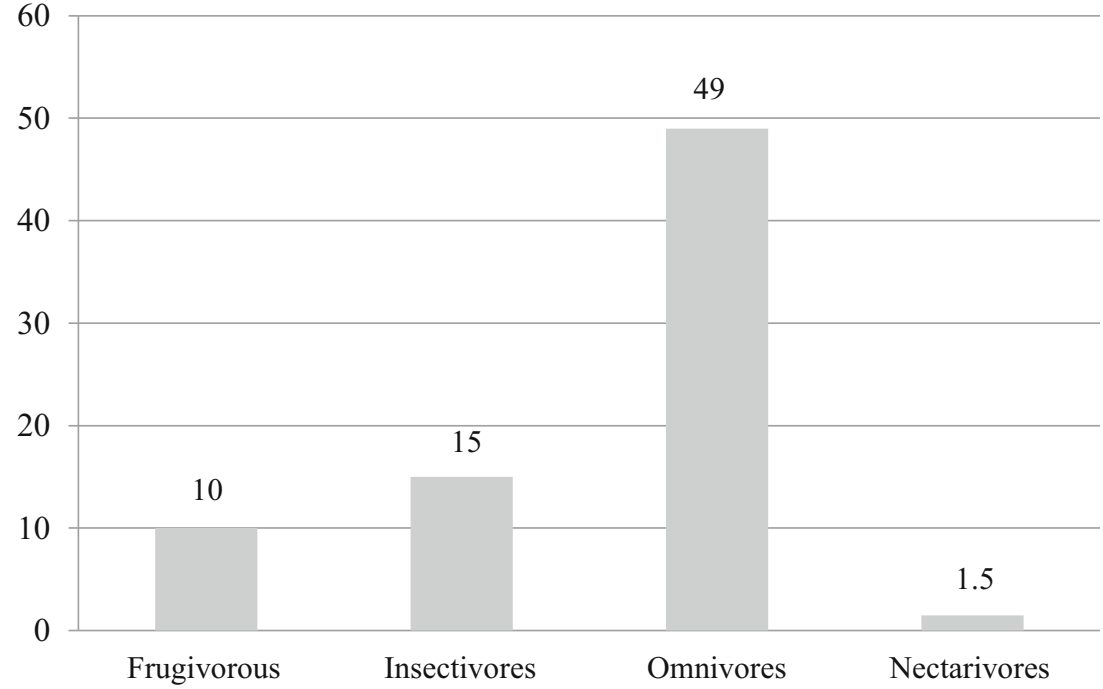

Table 4 List of helminth records in chiropters of South America, with their hosts and authors

\begin{tabular}{|c|c|c|c|}
\hline Helminths & Hosts & Authors & Hosts diagnosed in the present study \\
\hline \multicolumn{4}{|l|}{ Digenea } \\
\hline \multicolumn{4}{|l|}{ Anenterotrematidae } \\
\hline Anenterotrema liliputianum ${ }^{\mathrm{a}}$ & $\begin{array}{l}\text { Histiotus velatus; Molossus molossus; } \\
\text { Molossus rufus; } \\
\text { Molossidae gen. sp.; } \\
\text { Molossops temminckii; } \\
\text { Myotis nigricans; } \\
\text { Phyllostomus elongatus; } \\
\text { Peropteryx macroti }\end{array}$ & Santos and Gibson (2015) & $\begin{array}{l}\text { P. } \text { hastatus }^{\mathrm{b}} ; \text { G. soricina } \\
\text { M. rufus; C. perspicillata }\end{array}$ \\
\hline Anenterotrema eduardocaballeroi ${ }^{\mathrm{a}}$ & $\begin{array}{l}\text { Eumops glacinus; Eumops sp.; } \\
\text { Molossus rufus rufus; M. molossus; } \\
\quad \text { Phyllostomus elongatus; } \\
\text { P. hastatus; Histiotus velatus; } \\
\text { Eptesicus brasiliensis }\end{array}$ & $\begin{array}{l}\text { Lunaschi (2002); } \\
\text { Cardia (2012); } \\
\text { Santos and Gibson (2015) }\end{array}$ & $\begin{array}{l}\text { P. hastatus; C. perspicillata } \\
\text { M. molossus }\end{array}$ \\
\hline \multicolumn{4}{|l|}{ Lecithodendriidae } \\
\hline Ochoterenatrema caballero $i^{\mathrm{a}}$ & $\begin{array}{l}\text { Cynomops planirostris; Molossops sp.; } \\
\text { E. glaucinus; E. auripendulus; } \\
\text { M. rufus; M. molossus; Nyctinomops } \\
\text { laticaudatus; Nyctinomops macrotis; } \\
\text { Lasiurus cinereus; Promops nasutus }\end{array}$ & $\begin{array}{l}\text { Cardia (2012); Santos } \\
\quad \text { and Gibson (2015) }\end{array}$ & $\begin{array}{l}\text { Peropteryx } \text { kappleri }^{\mathrm{b}} \text {; } \\
\quad \text { C. perspicillata }{ }^{\mathrm{b}} ; \text { M. molossus }\end{array}$ \\
\hline \multicolumn{4}{|l|}{ Nematoda } \\
\hline \multicolumn{4}{|l|}{ Filariidae } \\
\hline Litomosoides brasiliensis $^{\mathrm{a}}$ & $\begin{array}{l}\text { Glossophaga soricina; } \\
\text { Phyllostomidae sp.; } \\
\text { Carollia perspicillata }\end{array}$ & $\begin{array}{l}\text { Vicente et al. (1997); } \\
\quad \text { Cardia (2012) }\end{array}$ & A. planirostris $^{\mathrm{b}}$ \\
\hline Litomosoides guiterasi $^{\mathrm{a}}$ & $\begin{array}{l}\text { Glossophaga soricina; } \\
\text { Glossophaga sp.; } \\
\text { Carollia perspicillata; } \\
\text { Anoura caudifer }\end{array}$ & $\begin{array}{l}\text { Vicente et al. (1997); } \\
\quad \text { Cardia (2012) }\end{array}$ & C. perspicillata \\
\hline \multicolumn{4}{|l|}{ Molineidae } \\
\hline Tricholeiperia sp. $^{\mathrm{a}}$ & - & - & C. perspicillata ${ }^{\mathrm{b}}$ \\
\hline Parahistiostrongylus octacanthus ${ }^{\mathrm{a}}$ & P. hastatus; Pteronotus parnellii & $\begin{array}{l}\text { Vicente et al. (1997); } \\
\text { Santos and Gibson (2015) }\end{array}$ & P. hastatus \\
\hline
\end{tabular}

\footnotetext{
${ }^{\mathrm{a}}$ Record of new locality
}

${ }^{\mathrm{b}}$ Record of new host 
Nogueira et al. 2004; Lord et al. 2012). It is suggested that estrogen stimulates the immune system, while testosterone causes suppression (Schalk and Forbes 1997). Male bats showed higher parasitic intensities in comparison to females, but there was no statistic correlation between sex and parasite intensity.

\section{Conclusions}

Amazon harbors most part of the Brazilian diversity of chiropteran species. However, this study showed that the richness of host species is not reflected on parasite diversity. The present study revealed that endoparasites did not cause impact on host body condition and sex did not influence the composition of helminth communities of bats, as well as the observed diversity was lower than that observed in higher latitudes. Therefore, Amazonian bats did not follow the expected pattern of host-parasite interactions found in non-flying mammals.

In Brazil, studies about bat parasites are scarce, so more research in other localities, not only in Amazon but also in other biomes of the country, should be conducted to obtain better understanding about ecological interactions that exist between helminths and chiropterans in Brazil.

Acknowledgments We are grateful to the "Conselho Nacional de Desenvolvimento Científico e Tecnológico" (CNPq) for the financial support and Norte Energia SA and Biota Projetos e Consultoria Ambiental Ltda. for the logistical support that made possible the execution of this research.

\section{Compliance with ethical standards}

Conflict of interest The authors declare that they have no conflict of interest.

\section{References}

Anthony ELP (1988) Age determination in bats. In: Kunz TH (ed) Ecological and behavioral methods for study of bats. Smithsonian Institution Press, Washington, pp 47-58

Bernard E, Tavares VC, Sampaio E (2011) Compilação atualizada das espécies de morcegos (Chiroptera) para a Amazônia Brasileira. Biota Neotropical 11(1):35-46

Bordes F, Morand S (2008) Helminth species diversity of mammals: parasite species richness is a host species attribute. Parasitology 135:1701-1705

Bush AO, Lafferty KD, Lotz JM, Shostak AW (1997) Parasitology meets ecology on its own terms: Margolis et al. revisited. J Parasitol 83: 575-583
Cardia DFF (2012) Helmintos de quirópteros da região Centro-Oeste do Estado de São Paulo. Tese, Faculdade de Ciências Agrárias e Veterinárias, Universidade Estadual Paulista

dos Reis NR, Fregonezi MN, Peracchi AL, Shibatta AO (2013) Morcegos do Brasil: Guia de campo. Technical Books, Rio de Janeiro

Esteban JG, Amengual B, Cobo JS (2001) Composition and structure of helminth communities in two populations of Pipistrellus pipistrellus (Chiroptera: Vespertilionidae) from Spain. Folia Parasitol (Praha) 48:143-148

Khalil LF, Jones A, Bray RA (1994) Keys to the cestode parasites of vertebrates

Lewis SE (1996) Low roost-site fidelity in pallid bats: associated factors and effect on group stability. Behav Ecol Sociobiol 39:335-344

Lima PM, Rodrigues ASL, Cunha NA, Lucas AS, Paulsen RMM, Müller G, Farias NAR, Santos TRB (2001) Fauna Parasitária de morcegos da área urbana de Pelotas, RS. J Bras Patol 37:212

Lindenfors P, Nunn CL, Jones KE, Cunningham AA, Sechrest W, Gittleman JL (2007) Parasite species richness in carnivores: effects of host body mass, latitude, geographical range and population density. Glob Ecol Biogeogr 16:496-509

Lord JS, Parker S, Parker F, Brooks D (2012) Gastrointestinal helminths of pipistrelle bats (Pipistrellus pipistrellus/Pipistrellus pygmaeus) (Chiroptera: Vespertilionidae) of England. Parasitology 139:366374

Lourenço SI, Palmeirin JM (2007) Can mite parasitism affect the condition of bat hosts? Implications for the social structure of colonial bats. J Zool 273:161-168

Lunaschi L (2002) Tremátodos Lecithodendriidae y Anenterotrematidae de Argentina, México y Brasil. Analesdel Inst Biol, Univ Nac Autónoma Méx, Ser Zoología 73(1):1-10

Marcon JL, Menin M, Araújo MGP, Hrbek T (2012) Biodiversidade Amazônica: caracterização, ecologia e conservação. Edua, Manaus

Melo LCV (2010) Estudo da fauna enteroparasitária de morcegos sinantrópicos do município de São Paulo/Brasil, no período de abril de 2007 a novembro de 2008, Dissertação, Coordenadoria de Controle de Doenças, Brasil

Miretzki M (2003) Morcegos do Estado do Paraná, Brasil (Mammalia, Chiroptera): Riqueza de espécies, distribuição e síntese do conhecimento atual. Papéis Avulsos de Zoologia 43(6):101-138

Ministério do Meio Ambiente-MMA (2014) Bioma Amazônia, Brasília, 2014. www.mma.gov.br/biomas/amazônia. Acessado 02 abril 2014

Nogueira MR, Fabio SP, Peracchi AL (2004) Gastrointestinal helminth parasitism in fruit-eating bats (Chiroptera, Stenodermatinae) from western Amazonian Brazil. Rev Biol Trop 52(2):387-392

Peracchi AL, Gallo PH, Dias D, Lima IP, Reis NR (2010) Ordem Chiroptera. In: Reis NRR, Peracchi AL, Fregonezi MN, Rossaneis BK (eds) Mamíferos do Brasil: guia de identificação. Technical Books, Rio de Janeiro, pp 293-461

Pinheiro MC, Ribeiro CCDU, Lourenço EC, Landulfo GA, Luz HR, Famadas KM, Rodrigues MLA (2013) Levantamento de enteroparasitos em morcegos através de técnica de centrífugo flutuação (Mammalia: Chiroptera) em área de Floresta Tropical. Neotropical Helminthol 7(1):143-147

Poulin R, Morand S (2000) The diversity of parasites. Q Rev Biol 75(3): 277-293

Reis NR, Peracchi AL, Sekiama ML, Lima IP (2000) Diversidade de morcegos (Chiroptera, Mammalia) em fragmentos florestais no estado do Paraná, Brasil. Rev Bras Zoologia 13(3):697-704

Reis NR, Peracchi AL, Pedro WA, Lima IP (2007) Morcegos do Brasil. Universidade Estadual de Londrina, Londrina

Santos CP, Gibson DI (1998) Apharyngotremalentin. sp., a new anenterotrematid trematode from the gall-bladder of some Amazonian bats, with comments on Anenterotrema Stunkard, 1938 and Apharyngotrema Marshall; Miller, 1979. Syst Parasitol 41:149-156 
Santos CP, Gibson DI (2015) Checklist of the helminth parasites of South American bats. Zootaxa 3937(3):471-499

Saoud MFA, Ramadan MM (1976) Studies on the helminth parasites of bats in Egypt and the factors influencing their occurrence with particular reference to digenetic trematodes. Zeitschriftfür Parasitenkunde 51:37-47

Schalk G, Forbes MR (1997) Male biases in parasitism of mammals: effects of study type, host age and parasite taxon. Oikos 78:67-74

Silva RJ (2012) Biodiversidade de Helmintos parasitos de animais ectotérmicos: saúde global e zoonose. Biologist 10(2):1
Travassos L, Freitas JFT, Kohn A (1969) Trematódeos do Brasil. Mem Inst Oswaldo Cruz 67:1-886

Vicente JJ, Rodrigues HO, Gomes DC, Pinto RM (1997) Nematóides do Brasil. Parte V: Nematóides de mamíferos. Rev Bras Zoologia 14:1-452

Vizotto LD, Taddei VA (1973) Chave para determinação de quirópteros brasileiros. Bol Ciências São José do Rio Preto 1:1-72

Von Zuben CJ (1997) Implicações da agregação espacial de parasitas. Rev Saúde Públicas 31(5):523-530

Wimsatt WA (1970) Biology of bats. Academic, New York

Zahn A, Rupp D (2004) Ectoparasite load in European vespertilionid bats. J Zool 262:383-391 